\title{
ANSERJ
}

Vol. 3, No 2

Fall / Automne, 2012

pp. $43-66$

Canadian Journal of Nonprofit and Social Economy Research

Revue canadienne de recherche sur les OBSL et l'économie sociale

\section{Community Development to Feed the Family in Northern Manitoba Communities: Evaluating Food Activities Based on Their Food Sovereignty, Food Security, and Sustainable Livelihood Outcomes}

Shirley Thompson, Asfia Gulrukh Kamal

Natural Resources Institute, University of Manitoba

Mohammad Ashraful Alam

Environment \& Geography, University of Manitoba

Jacinta Wiebe

Assiniboine Community College and Berens River First Nation

\begin{abstract}
This article explores food-related activities and their impacts on sustainable livelihood assets, food sovereignty, and food security, and provides insight for future food-related community development. Analysis is based on community food assessments conducted in 14 Northern Manitoba communities and included a food security survey, price survey, and interviews. The lack of community control over development in First Nation and other Northern remote and rural communities in Northern Manitoba is found to undermine both food sovereignty and sustainable livelihoods, while creating high levels of food insecurity. According to logit models, sharing country foods increases food sovereignty and sustainable livelihoods, and has a stronger relationship to food security than either road access to retail stores in urban centres or increased competition between stores. The model predicts that rates of food insecurity for a community with a country foods program and with access to public transit and roads at $95 \%$ would be lower than the Canadian average of $92 \%$.
\end{abstract}

\section{RÉSUMÉ}

Cet article explore les activités relatives à l'alimentation et leur impact sur les biens durables ainsi que sur la souveraineté et la sécurité alimentaires tout en ouvrant des perspectives sur le développement communautaire futur relatif à l'alimentation. L'analyse se fonde sur une recherche menée dans quatorze communautés du nord du Manitoba et comprend un premier sondage sur la sécurité alimentaire, un second sondage sur les prix, et des entrevues. Le manque de contrôle du développement dans les communautés reculées du nord du Manitoba, tant autochtones que non-autochtones, mine à la fois la souveraineté alimentaire et les moyens 
d'existence durables tout en provoquant de hauts niveaux d'insécurité alimentaire. Selon un modèle Logit, le partage d'aliments locaux permet une souveraineté alimentaire et une autonomie durable tout en ayant un meilleur impact sur la sécurité alimentaire que celui obtenu par l'accès routier aux supermarchés des centres urbains ou par une concurrence accrue entre détaillants. Le modèle indique même que les taux d'insécurité alimentaire pour une communauté rurale ayant un programme de nourriture locale et l'accès au transport en commun seraient, à 95\%, inférieurs à la moyenne canadienne de $92 \%$.

Keywords / Mots clés : Food-related economic development; Community economic development; Food sovereignty; First Nations; Country foods; Sustainable livelihoods; Food security / Développement économique alimentaire; Développement économique communautaire; Souveraineté alimentaire; Premières Nations; Aliments locaux; Moyens d'existence durables; Sécurité alimentaire

\section{INTRODUCTION}

What can be done to sustain and feed communities in Northern Manitoba, where families are poor and retail food prices are extremely high? Problems associated with food access in remote fly-in communities in Manitoba include limited selection of perishable foods, high food prices, escalating transportation costs, uncertainty of travel on winter ice roads, high poverty rates, and a declining use of local country foods (Northern Food Prices Project Steering Committee [NFPSC], 2003; Thompson et al., 2011a, 2011b). The re-invigoration of local food production is considered key to food access (NFPSC, 2003). Community-based food action is one possible response to tackle food insecurity, alongside business activities, government programs, and social policy (Power, 1999; Power \& Tarasuk, 2006).

This study evaluates food activities in 14 different fly-in or rural communities in Northern Manitoba (see Figure 1), with the goal of informing future community and policy development. This evaluation considers food sovereignty, food security, and community assets for sustainable livelihoods resulting from each food activity, including corporate, government, and community-driven food activities. Indigenous peoples refers to all people who have an historical continuity with pre-invasion and pre-colonial societies that developed on their territories.

The term "Aboriginal" applied in this article is a Canadian term that includes First Nation (FN), Metis, and Inuit peoples, and in this article refers to the Anishinaabe, Oji-Cree, Cree, Dene and Metis peoples in the 14 Northern Manitoba communities. These communities include First Nation reserves, which are regulated and funded by the federal government, and non-reserve communities, which are regulated and funded provincially by Manitoba's Department of Aboriginal and Northern Affairs (ANA) and are referred to as ANA communities.

\section{COMMUNITY DEVELOPMENT}

Douglas describes community development (CD) as "communities addressing problems and opportunities, on their own behalf, which they perceive to be of importance to their quality of life or their community's viability" (1994, p. 10). "Community" is a geographical term that considers infrastructure, services, expertise, the availability of natural resources, and vulnerabilities in a given locale. Food related CD builds local capacity or livelihood assets to resolve issues of poverty, hunger, and inequality (Shragge, 2003) through a "participatory, bottom-up approach to development" (Markey, Pierce, Vodden, \& Roseland, 2005, p. 2). Self-sufficiency, decision-making, and ownership (Loxley, 1986) are key to CD and, in the context of food activities, point to the need for food sovereignty. Douglas (1994) raises many questions about CD that are pertinent to this analysis, namely: what is being developed, by whom, how is it being developed, and on whose behalf? When looking at food activities, these questions become: how does this activity impact food security, food sovereignty, and community assets for sustainable livelihoods?

\section{ANSERJ To be notified about new ANSERJ articles. click subscribe.}


Figure 1: Location of communities surveyed in Northern Manitoba

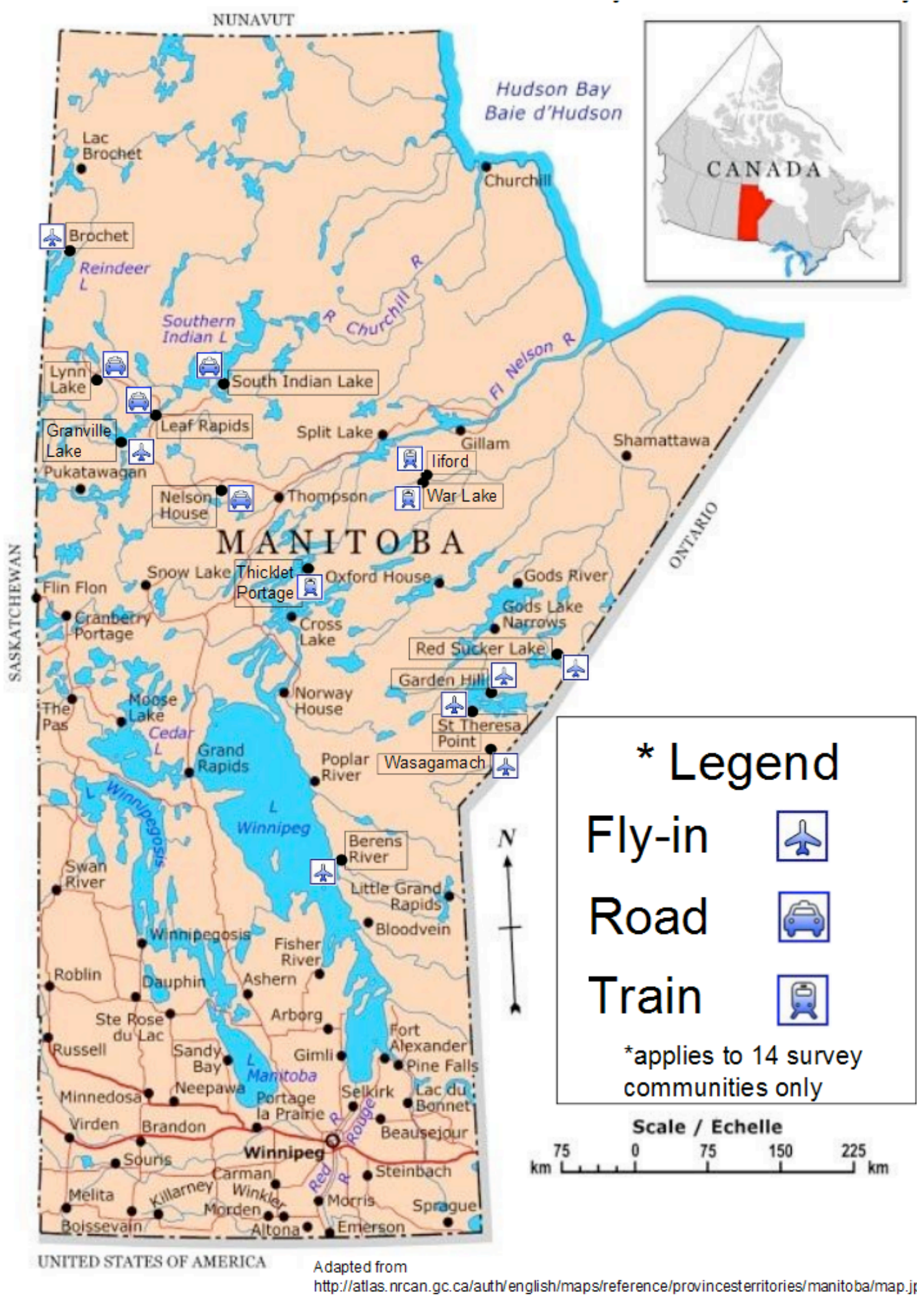


Community food projects often include the development of practical economic alternatives to the prevailing corporate food production and provisioning system (Sonnino \& Marsden, 2006). For example, British Columbia's Community Food Action Initiative requires each Health Authority to work with communities in their jurisdiction to develop Food Security Plans (BC Health, 2012). Plans detail financial support for community-led solutions that include community gardens, farmers' markets, community planning initiatives, supports for local food production, healthy food for public buildings, creation of community capacity, community food assessments, and the development of local food charters and policies (BC Health, 2012). Such programming encourages socially equitable and ecologically sound practices (Feenstra, 1997) by reducing the "food miles" between producers and consumers (Shragge, 2003) and enabling the poor and underprivileged consumers to be producers to resolve their own food security. In contrast, the free market system excludes poor people in terms of access and control, thus creating dependency rather than self-sufficiency (Wiebe, 2012). Successful food system interventions in Indigenous communities (Kuhnlein, 2008) around the globe have four common characteristics: 1) traditional food harvesting, 2) agricultural and gardening activities, 3) education about food production and nutrition, and 4) growing community food plans through collaboration.

\section{INDIGENOUS COMMUNITY DEVELOPMENT}

According to Winona LaDuke (2002), development in Indigenous communities should be based on the Indigenous concept of Minobimaatisiiwin, an Anishinaabe (also known as Ojibway or Chippeway) word signifying "good life" or "continuous rebirth" (p. 79). Indigenous development requires an Indigenous worldview that considers cyclical thinking, reciprocal relations, and responsibilities to the earth, creation, and decentralization (Ballard, 2012). To be holistic, Indigenous development must consider physical, governance, and economic aspects, but also the people themselves, animals and water (Wiebe, 2012). Any type of development project should therefore incorporate Indigenous knowledge in the design, implementation, and review stages. According to Wiebe (interview, 2012), a FN community developer, "[t]he day that Aboriginal people take control of their own community planning and governance is the day that we will begin to see positive changes."

The Arctic Co-operatives Limited supports Indigenous development, namely through 31 community-based businesses in Nunavut and the Northwest Territories (Arctic Co-operatives Limited, 2012). The 31 Co-operatives are independently owned and operated, employing 900 people in grocery stores, retail sales, arts and crafts production, and other businesses, in order to meet the needs of the Inuit and Dene communities in which they are based. Arctic Co-operatives has its head-office in Winnipeg, Manitoba, but has generally not done business in Manitoba except for one unsuccessful grocery store in one Northern Manitoban community.

\section{FOOD SECURITY}

Food security occurs "when all people, at all times, have physical and economic access to sufficient, safe and nutritious food that meets their dietary needs and food preferences for an active and healthy life" (FAO, 1996, p. 1). The five universal pillars of food security include availability, accessibility, acceptability, adequacy, and action, but a sixth pillar, country food harvesting and sharing, is also considered important in Indigenous communities (Power, 2008).

Food insecurity is a consequence of inadequate or uncertain access to healthy food in terms of quantity or quality, and is most often associated with poverty (Tarasuk, 2009). Food insecurity is reflected in unhealthy dietary patterns such as a low intake of fruits and vegetables (Che \& Chen, 2001; Scheier, 2005), and is linked to broader food-related health problems such as obesity, heart disease, diabetes, high blood pressure, distress, depression, low immunity levels,

\section{ANSERJ To be notified about new ANSERJ articles. click subscribe.}


dental caries, anemia, and other chronic conditions (Ford \& Mokdad, 2008; Kirkpatrick \& Tarasuk, 2008; Ledrou \& Gervais, 2005; Willows, Hanley, \& Delormier, 2012). The decline in subsistence activities by First Nation peoples has decreased their levels of food security (Thompson, 2005), and resulted in higher rates of obesity, dental caries, anemia, diabetes, and lowered resistance to infection (Szathmary, Ritenbaugh, \& Goodby, 1987; Thouez, Rannou, \& Foggin, 1989; Willows, Veugelers, Raine, \& Kuhle 2011; Willows et al. 2012). Food insecurity, with its dire consequences, demonstrates the need for high-impact food programs.

\section{Food sovereignty}

According to the Declaration of Nyéléni, food sovereignty is "the right of peoples to healthy and culturally appropriate food produced through ecologically sound and sustainable methods, and their right to define their own food and agriculture systems" (International Planning Committee for Food Sovereignty, 2007, p. 1). The food sovereignty movement was initiated by peasant and Indigenous organizations (Altieri, 2008; Holt-Giménez, Patel, \& Shattuck, 2009) that realized the need for land redistribution and protection of their territory (Torrez, 2011). Access to land is a struggle for Northern Manitoba's Indigenous peoples, as settlers usurped their territorial lands for their own development (Ballard, 2012). "Usufruct rights" for low-scale, intergenerational economic practices on ancestral territories can forclose environmentally destructive development, particularly hydroelectric damning in Northern Manitoba, and government policies (LaDuke, 2002). Food sovereignty considers that people have to make both a living and eat, linking it to the related concepts of food security and sustainable livelihoods.

\section{Sustainable livelihoods}

The concept of sustainable livelihoods considers assets (natural, physical, human, financial, and social capitals) that determine how people make a living (Ellis 2000) can be applied not only to the households (Scones, 2012) but also to the community and regional context (Thompson et al., 2011a: Ballard, 2012). A sustainable livelihoods analysis is generally lacking from CD evaluation (Brocklesbury \& Fisher, 2003), however in this study it is applied to 14 Northern Manitoba communities to show the general context for development and capacity building. The status of these five assets in Northern Manitoba are: 1) Human capital (that is, the skills, health, and education of individuals that contribute to the productivity of labor and capacity to manage land) is limited, given the relatively low levels of education, high rates of chronic unemployment, and high rates of disease compared to other communities in Canada (Statistics Canada, 2006); 2) Social capital (that is, the close social bonds that facilitate cooperative action, social bridging, and linking to share and access ideas and resources), once strong, has been weakened by the residential school system, reserve settlements, and the settler education (LaDuke, 2002), resulting in few opportunities for Aboriginal peoples to influence policies, programs, and their own development (Thompson et al., 2011a; Ballard, 2012); 3) Natural capital (that is, resources and land management practices) is abundant in the form of fisheries, forests, minerals, and non-timber, however FNs have no regulatory or ownership rights to resources in their territories (Thompson et al., 2011a,b; Ballard, 2012; LaDuke, 2002); 4) Physical capital (that is, equipment and infrastructure) is inadequate in Northern Manitoba without roads connecting communities together, nor adequate housing, safe drinking water, or, in the case of Brochet, electrical grid access (infrastructure in nearby ANA communities is typically better than in FN communities); 5) Financial capital (that is, savings and credit) is generally low, particularly on FN reserves, as their land and housing is the property of the Crown (Ballard, 2012); without collateral, FN peoples have limited ability to obtain credit to build enterprise. With this context in mind, this study will apply these "capitals" to the different food activities. 
Figure 2: The context of sustainable livelihoods and Community Economic Development (CED) for food related development

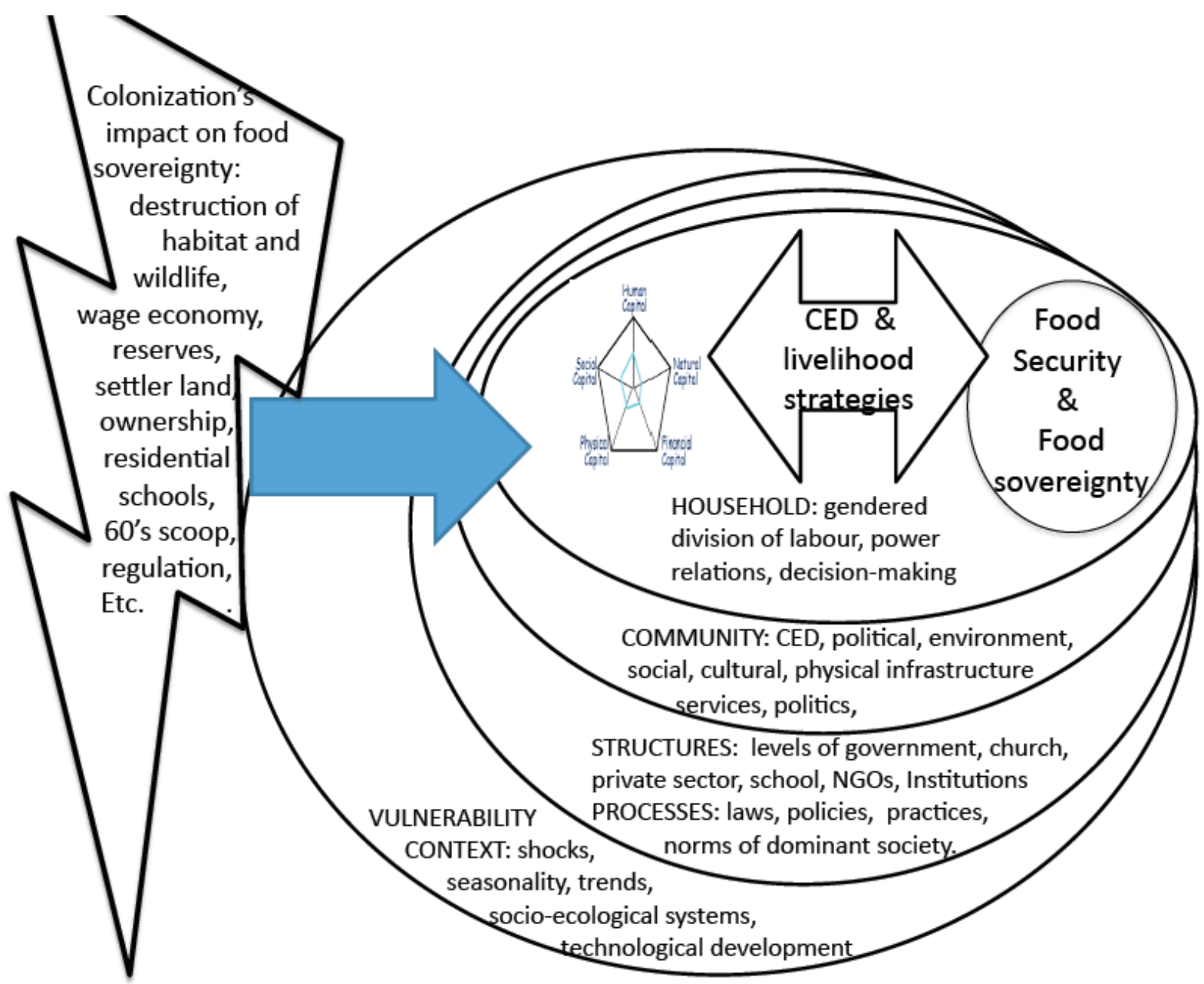

Institutional structures (e.g., rules, customs, and land tenure) and processes (e.g., laws, policies, societal norms, and incentives) operate at multiple levels (e.g., regional, government and multinational corporations) to either create barriers to sustainable livelihoods, or facilitate them (Carney, 1998; Ellis, 2000; Scoones, 1998). Institutional structures such as the Indian Act, and other colonial policies that continue to this day, take away local decisionmaking powers, and have resulted in a state in which many FN communities in Northern Manitoba are currently under third party management (Ballard, 2012), by requirement of the federal government whereby accounting firms controlling their funding and management). Residential schools and the "Sixties Scoop"-which refers to the Canadian practice beginning in the 1960s and continuing until the late 1980s, of apprehending unusually high numbers of FN children, sending them to foster homes or putting them up for adoption (usually into white families)created a loss of cultural identity, a break in family ties, and widespread harm to children (Ballard, 2012). Figure 2 illustrates the impact of new and old colonial structures at the individual, household, and community level on food sovereignty. Amartya Sen's (1983) discussion of how a person's assets impact food security, applies perfectly to FN peoples applies perfectly to our analysis of Northern Manitoba communities: "a person is reduced to starvation if some change occurs either in his [or her] endowment (e.g., alienation of land, loss of labor power, ill health) or in his [or her] exchange entitlement (e.g., fall in wages, rise in food prices, loss of employment, drop in price of foods [she 
or] he produces)" (p. 45). FN community members are alienated from their territory and placed on Crown reserve land, with little exchange entitlement due to the fall in the fur trade and other markets, and with few employment and higher education opportunities.

\section{METHODOLOGY}

A participatory process was undertaken with 14 communities and five non-government organizations (NGOs) between 2008, when University of Manitoba (U of M) ethics approval was received (J2008, p. 113), and the summer of 2012. Seven economic activities occurring in Northern Manitoba are analyzed to determine their contribution to: 1) food security, 2) food sovereignty, and 3) sustainable livelihoods (applying the five capitals previously discussed namely: natural, physical, human, financial, and social) by the following four methods:

1. A Community Food Assessment (CFA) is a collaborative and participatory process to systematically examine a broad range of community food issues and assets, so as to inform and build capacity for community food security (Cohen, 2002). CFAs were initiated in 2009 with key community members (e.g., school principals, health workers, councilors, chiefs or mayors) from each of the 14 communities. The goal was to train key community members, and to assist in their efforts to examine resources and needs, and to improve food sovereignty. This participatory research included observation, tours, interviews (with transcripts), and field notes (which underwent systematic content analyses). Subsequent community-driven food-related activities, in partnership with the University of Manitoba $(\mathrm{U}$ of $\mathrm{M})$, have resulted at Garden Hill FN, South Indian Lake FN, and the Town of Leaf Rapids.

2. Participatory video (PV) techniques were used to engage people from the 14 communities in a process of shaping and creating films that tell their "food story." Several PV workshops were held with community members, and written consent was obtained during PV interviews to identify most participants' names. Draft versions of each film were screened at different events to provide community members on-going input into their storyline. Based on community input, after the screenings more interviews took place and additional scenes were added. Videos were posted at http://home.cc.umanitoba.ca/ thompso4/ and were widely circulated. Growing Hope in Northern Manitoba, which was featured in Intercontinental $\mathrm{Cry}$, an international newspaper, was viewed by more than 3000 people. As well, in an effort to influence policy, the film Harvesting Hope in Northern Manitoba, was shown at a number of film festivals and conferences, and at meetings of Manitoba's Rural Secretariat and the Department of Aboriginal Affairs and Northern Development Canada, in Ottawa, Canada, in 2010 and 2011. In addition, the film The Burntwood Journey: Chronic Disease Prevention Initiative in Northern Manitoba was distributed by the Burntwood Regional Health Authority to community members at health conferences. This film served as a key tool in evaluating the program, and ultimately contributed to this pilot project becoming a permanent program.

3. The National Nutritious Food Basket (NNFB) survey (Health Canada, 2008) provides a standardized shopping list of 60 goods that was used to assess grocery stores in 14 Northern Manitoba communities and 22 grocery stores in Southern Manitoba in 2009. The NNFB list, if sized to a family or individual, represents a nutritious diet based on current dietary guidelines and food consumption data; however, the list was used strictly for the purposes of costs comparison. 
4. A household food security survey was carried out with 533 households in 14 communities using a validated instrument from Health Canada (2007). The survey was used to estimate both the prevalence of food insecurity and its severity (Health Canada, 2007). To complement the survey, households were asked additional questions regarding garden provisioning and hunting and fishing. Additionally, community level data on greenhouses and store access were collected through observation and interviews. Data analysis was conducted using descriptive and inferential statistics by STATA 11. Logistic regression (logit) was used to provide insight into how certain food-related activities impacted food security, because the dependent variable of food security has a binary discrete value (i.e., yes or no) (Pindyck \& Rubinfeld, 1991). Logit models are useful in this type of data analysis because they can establish the probability of various events occurring under a given set of conditions (Pindyck \& Rubinfeld, 1991). The probabilities for food security were determined by the presence or absence of different economic activities and development related to theory (FAO, 1996; Power, 2008). Attaining food security was hypothesized as a positive function of the: 1) availability of retail food stores in the community - a continuous variable from zero to three stores; 2 ) accessibility to store(s) - due to the complexity of accessibility in Northern Manitoba, it has three different measures, namely: (2-1) stores are accessible by walking (yes/no); (2-2) roads provide access to urban centre (yes/no); and (2-3) public transit (e.g., bus or train) provides access to urban centres (yes/no); 3) acceptable food obtained from household hunting and fishing (yes/no); 4) adequacy in garden programming was rated from zero to five, based on whether gardens met none to all of a household's vegetable needs; 5) action was measured by the number of greenhouses in each community from zero to four; and 6) ability to harvest, share, and consume "country foods" was based on whether the community had a country foods program (yes/no).

The 14 communities, shown in Figure 1, were chosen from a list of rural communities that either lacked all weather roads or had a location north of Thompson, Manitoba (north of 55.45 degrees latitude). Amongst these communities, NGOs working on Northern food issues chose seven communities with best practices in food programming, and another seven for their limited uptake in food programming: these included nine FN communities and five ANA communities. A list of the households in each community was obtained, and each household was assigned a number. For each community a random number generator selected 100 numbers (noting that many communities were small with less than 100 households, with four having fewer than 25 households) corresponding to households. A surveyor visited each of the selected households and conducted a survey, if an adult was home and willing to participate. The survey population represents roughly $25 \%$ of the total population of the 14 communities, with the sample representing more than $5 \%$ of the total population of all remote and rural communities in Northern Manitoba (Department of Indian and Northern Affairs Canada, 2008; Statistics Canada, 2006; Thompson, Mailman \& Gulrukh, 2010b ).

\section{FINDINGS AND DISCUSSION}

\section{The need for food-based community economic development}

The survey ( $n=533$ ) found that adults and/or children experience food insecurity in three of every four households $(75 \%)$ in Northern Manitoba, leaving the remaining quarter $(25 \%)$ of households food secure. Figure 3 shows that one-third of homes $(33 \%)$ experience severe food insecurity, while more than two in five $(42 \%)$ experience moderate food insecurity. As shown in Figure 4, food security varies by both rate of incidence and severity, with plane access communities experiencing much higher rates and severity of food insecurity. 
Figure 3: Household food security status of households in Northern Manitoba Aboriginal communities ( $n=533$ households) in 14 communities

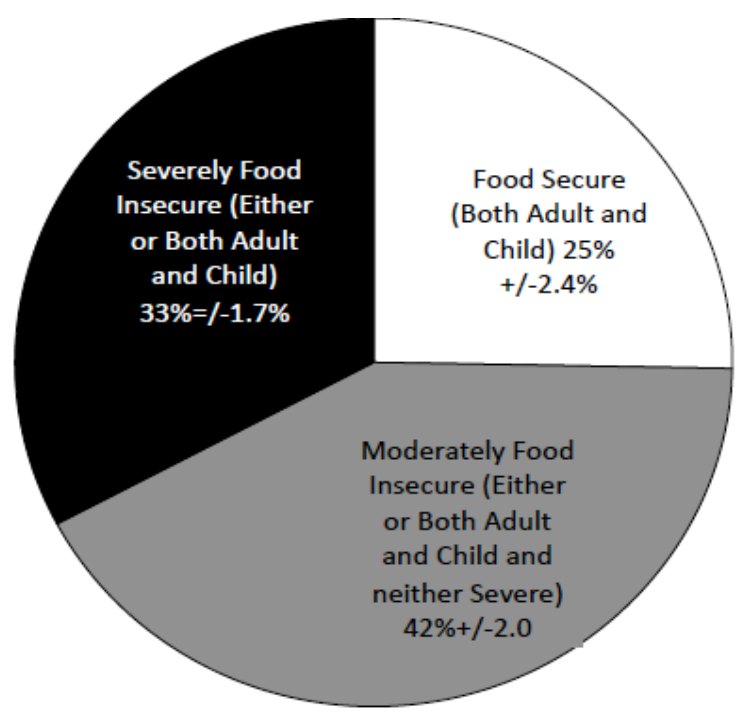

Table 1: Accessibility of communities input into food security analysis

\begin{tabular}{|c|c|c|c|c|c|c|c|c|}
\hline \multirow[b]{2}{*}{ Community } & \multirow[b]{2}{*}{$\begin{array}{l}\text { Community } \\
\text { Type }\end{array}$} & \multirow[b]{2}{*}{$\begin{array}{c}\text { Number } \\
\text { of } \\
\text { grocery } \\
\text { stores }\end{array}$} & \multicolumn{5}{|c|}{$\begin{array}{c}\text { Access } \\
(0=\text { No, } 1=\text { Yes })\end{array}$} & \multirow[b]{2}{*}{$\begin{array}{l}\text { Total House } \\
\text { Holds in } \\
\text { survey } \\
(N)\end{array}$} \\
\hline & & & $\begin{array}{l}\text { Distance } \\
\text { from } \\
\text { urban } \\
\text { centre } \\
\text { (km by } \\
\text { road) } \\
\end{array}$ & $\begin{array}{c}\text { Roa } \\
\text { d }\end{array}$ & Fly-in & Train & $\begin{array}{l}\text { Barge } \\
\text { for } \\
\text { food }\end{array}$ & \\
\hline Berens River & First Nation & 3 & 273 & 0 & 0 & 0 & 1 & 49 \\
\hline $\begin{array}{l}\text { Brochet (Barren } \\
\text { Lands) }\end{array}$ & First Nation & 1 & 610 & 0 & 1 & 0 & 0 & 50 \\
\hline Garden Hill & First Nation & 1 & 616 & 0 & 1 & 0 & 0 & 41 \\
\hline Granville & Non First Nation & 0 & 328 & 0 & 1 & 0 & 0 & 8 \\
\hline Ilford & Non First Nation & 0 & 205 & 0 & 0 & 1 & 0 & 10 \\
\hline Lynn Lake & Non First Nation & 1 & 324 & 1 & 0 & 0 & 0 & 46 \\
\hline Leaf Rapids & Non First Nation & 1 & 234 & 1 & 0 & 0 & 0 & 96 \\
\hline Nelson House & First Nation & 1 & 88 & 1 & 0 & 0 & 0 & 49 \\
\hline Red Sucker Lake & First Nation & 1 & 702 & 0 & 1 & 0 & 0 & 42 \\
\hline $\begin{array}{l}\text { South Indian } \\
\text { Lake }\end{array}$ & First Nation & 1 & 345 & 1 & 0 & 0 & 0 & 45 \\
\hline St. Theresa PT & First Nation & 1 & 600 & 0 & 1 & 0 & 0 & 39 \\
\hline Thicket Portage & Non First Nation & 0 & 138 & 0 & 0 & 1 & 0 & 20 \\
\hline Wasagamack & First Nation & 1 & 613 & 0 & 1 & 0 & 0 & 23 \\
\hline War Lake & First Nation & 0 & 205 & 0 & 0 & 1 & 0 & 15 \\
\hline Total & & & & & & & & 533 \\
\hline
\end{tabular}


Tables 1 to 3 provide the logit model and chi-square test inputs and results. Chi-square tests the null hypothesis that the coefficients of all the independent variables equal zero (Pindyck \& Rubinfeld, 1991). The null hypothesis is rejected at $P<0.0001$, indicating that the model has significant explanatory power. The percentage of correct predictions is also very high, explaining food security variation $78 \%$ of the time. The logit model had many statistically significant variables with 1) country food programs being the most important to food security rates followed by; 2) accessibility to urban marketplaces by roads; 3) public transit access; 4) the number of grocery stores in a community; and 5) degree of household gardening provisioning.

\section{Table 2: Definition and descriptive statistics of the explanatory variables used in the logit analysis}

\begin{tabular}{|c|c|c|c|c|c|}
\hline \multirow{2}{*}{ Label } & \multirow{2}{*}{ Description } & \multicolumn{2}{|c|}{$\begin{array}{l}\text { Categorical } \\
\text { Variables }\end{array}$} & \multicolumn{2}{|c|}{$\begin{array}{l}\text { Continuous } \\
\text { Variables }\end{array}$} \\
\hline & & Mean & SE & Mean & SE \\
\hline $\begin{array}{l}\text { Household Food } \\
\text { Security (Dependent } \\
\text { Variable) }\end{array}$ & $\begin{array}{l}1 \text { if Household has food security; } 0 \\
\text { otherwise }\end{array}$ & 0.23 & 0.02 & & \\
\hline Grocery Store & $\begin{array}{l}\text { Number of grocery stores in the } \\
\text { community }\end{array}$ & & & 1.09 & 0.03 \\
\hline Road Access & 1 if accessible by road only; 0 otherwise & 0.53 & 0.02 & & \\
\hline Country Food & $\begin{array}{l}1 \text { if country food program exists; } 0 \\
\text { otherwise }\end{array}$ & 0.10 & 0.01 & & \\
\hline Garden Food & $\begin{array}{l}\text { How often you receive food from garden; } \\
1=\text { never, } \\
2=\text { occasionally, } 3=\text { sometimes } \\
4=\text { regularly, } 5=\text { all the time }\end{array}$ & 1.29 & 0.04 & & \\
\hline Green House & Number of Green Houses in 2009 & & & 1.58 & 0.08 \\
\hline Public Transportation & 1 if public transit available; 0 otherwise & 0.54 & 0.02 & & \\
\hline $\begin{array}{l}\text { Compact community } \\
\text { design }\end{array}$ & 1 if community is compact; 0 otherwise & 0.19 & 0.02 & & \\
\hline Hunting/fishing & $\begin{array}{l}1 \text { if hunting/fishing in household; } 0 \\
\text { otherwise }\end{array}$ & 0.91 & 0.01 & & \\
\hline
\end{tabular}

Table 3: Logistic regression analysis results for food security model

\begin{tabular}{lrrrrr}
\hline & \multicolumn{2}{c}{ Odds Ratio } & \multicolumn{2}{c}{ Marginal Effect } \\
& $(\beta)$ & $95 \% \mathrm{CI}$ & $\mathrm{dy} / \mathrm{dx}$ & \multicolumn{1}{c}{$\begin{array}{c}\text { Std. } \\
\text { Error }\end{array}$} & $P$-value \\
\hline Grocery Store & & & & \multicolumn{3}{c}{0.03} \\
Road access only & 1.85 & $1.26-2.70$ & 0.10 & 0.03 & 0.002 \\
Country food program & 7.60 & $1.12-51.50$ & 0.31 & 0.13 & 0.038 \\
Food from garden & 20.64 & $2.42-176.08$ & 0.64 & 0.18 & 0.006 \\
Number of greenhouses & 1.41 & $1.01-1.81$ & 0.05 & 0.02 & 0.006 \\
Public Transit & 1.43 & $0.93-2.18$ & 0.06 & 0.03 & 0.099 \\
Compact community & 3.90 & $1.52-9.90$ & 0.22 & 0.07 & 0.005 \\
Hunting/Fishing & 1.62 & $0.71-3.70$ & 0.08 & 0.07 & 0.256 \\
& 0.90 & $0.43-2.28$ & -0.001 & 0.06 & 0.980 \\
\hline
\end{tabular}

\section{ANSERJ To be notified about new ANSERJ articles. click subscribe.}




\section{Food-related economic and development activities}

The impacts on food security, food sovereignty, and sustainable livelihood assets are described for each of the seven food activities below.

\section{Country food programs}

Country food programs are organized initiatives that support people living off the land in order to feed the local community (Thompson et al., 2011a). The term "country food" refers to the mammals, fish, plants, berries, and waterfow//seabirds harvested from local stocks. In Manitoba, the Nisichawayasihk Cree Nation (referred to as NCN or Nelson House FN) distributes traditional wild food to community members through the "Nelson House Country Food Program." Ron Spence, Councilor at NCN talked about how local funding and community direction results in food sovereignty: "Country foods is a program that is created by the community. If we were government funded then we'd be regulated. There would be a lot of things we couldn't do. That is why we are keeping this internally and locally operated" (Interview, 2010).

Figure 4: Food security rates in the 14 different communities

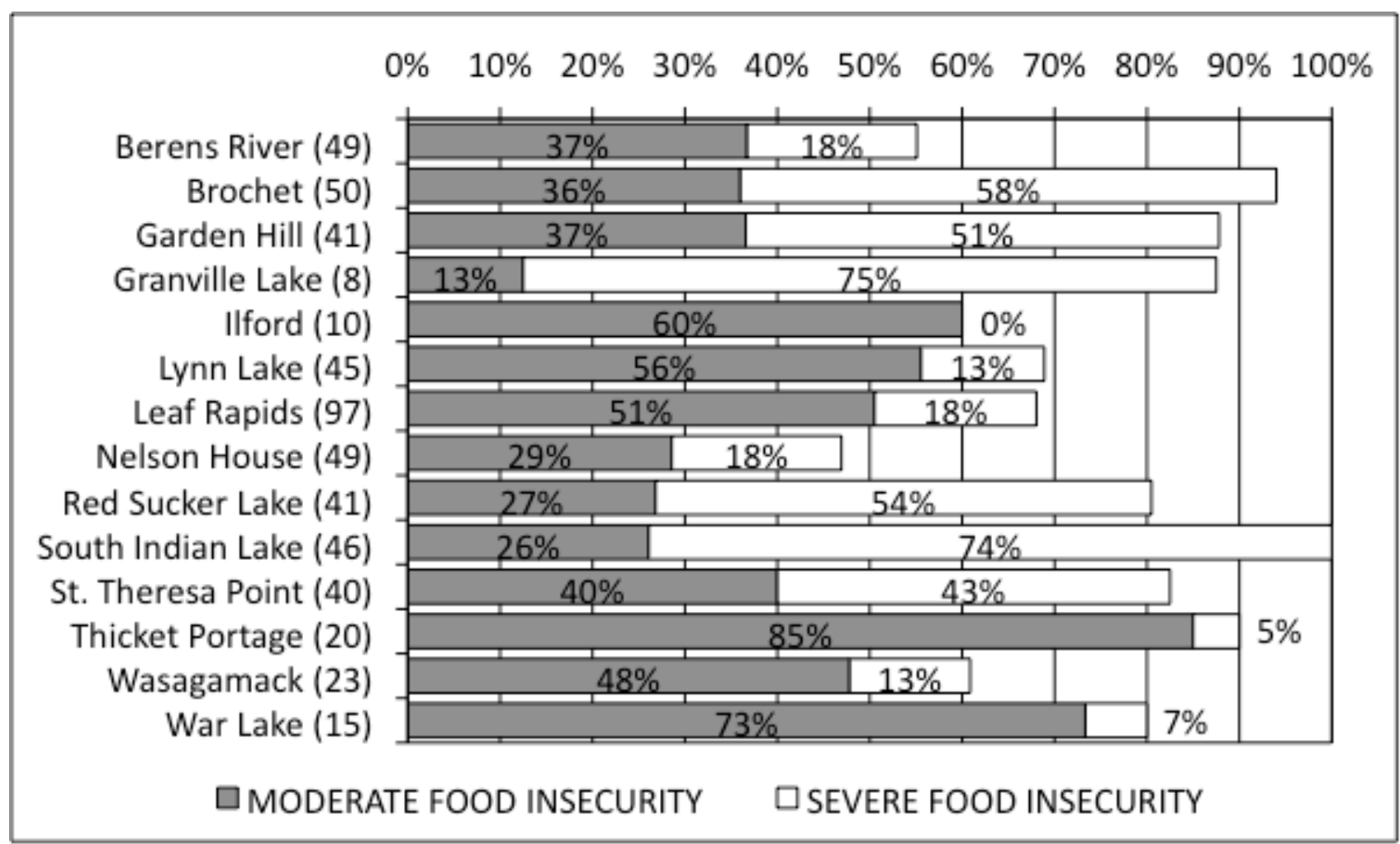

The country foods program is related to better food security. According to the logit model, sharing country foods was found to be more important to food security than any of the five conventional food security pillars (OR $20.64,95 \% \mathrm{Cl} 2.41-176.08, \mathrm{P}<0.01$ ). Figure 4 shows that of all 14 communities surveyed, rates of severe and moderate household food insecurity were lowest in NCN FN (47\%). Community members attributed their 
relative food security to the country food program. As shown in Figure 5 , a community with a country foods program but no public transit or roads is predicted to be $40 \%$ food secure, which is $15 \%$ higher than the current average rate of food security in Northern Manitoba $(25 \%)$. The model also suggests that when a country foods program is combined with good access to public transit and roads, the rate of food security at $95 \%$ would be higher than the Canadian average at $92 \%$.

\section{Figure 5: Predictive model of food security implementing different combinations of country foods program, roads and public transit}

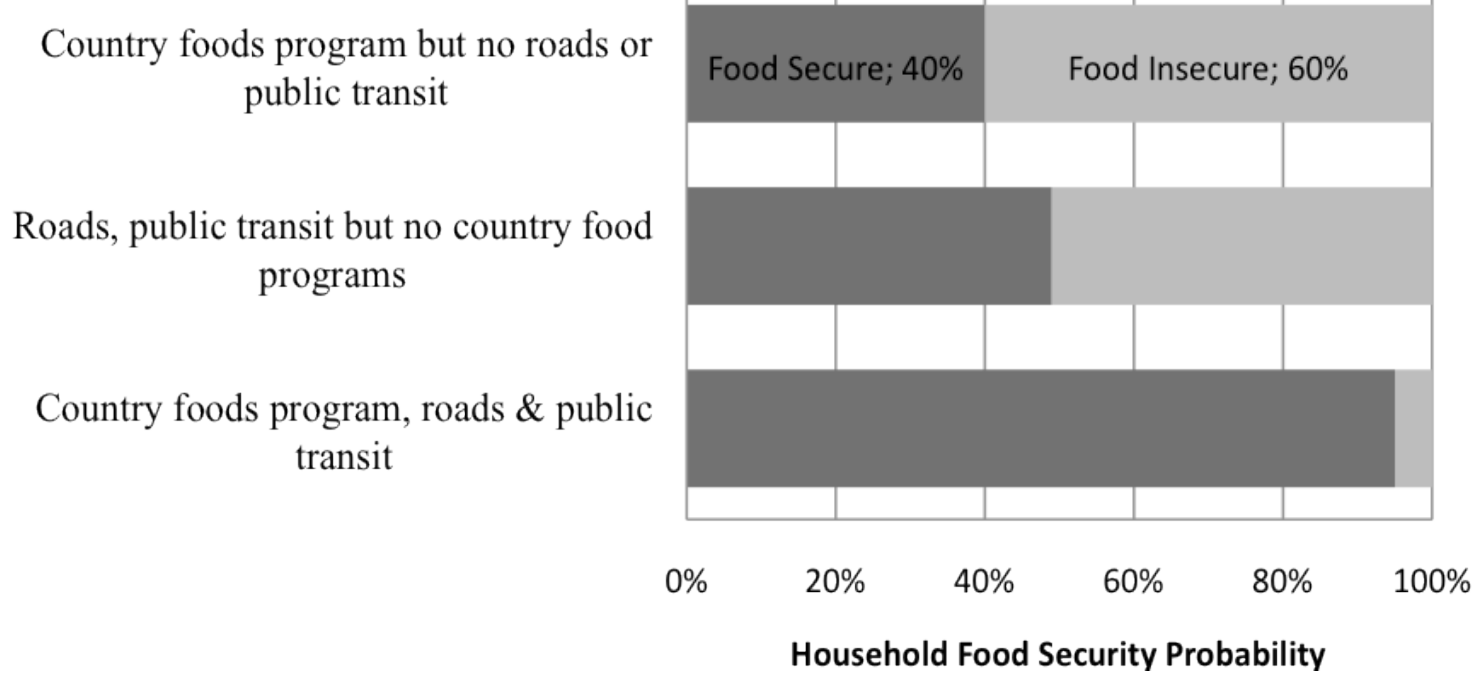

The Nelson House Country Food Program increases all of the sustainable livelihood assets. NCN has physical capital, including a processing centre for country foods, equipment to butcher meat, and freezers to store fish, berries, vegetables and meat. Human capital is gained by employing and training seven local people to hunt and fish year-round and share their Indigenous knowledge. Ron Spence stated: "Applying the culture and traditional aspect, like the smoking of fish and meat ... We promote the teaching of cultural values and traditional skills" (Interview, 2010). The workers track the foods received and disbursed for wildlife conservation purposes and public health safety. Country food increases social capital, providing food for pivotal community events such as weddings, funerals, and other cultural events where food is distributed freely amongst community members (prioritizing the needs of Elders, the sick, single-parent families, and other low-income individuals). According to Charlie Hart, the past Program Coordinator, most people in the community benefit from the country food program:

We are providing food to 1500 people out of 2500 [people in the community] and all of them are happy getting fresh meat and fish. It's a good way to maintain traditional culture in a healthy manner and others should try to implement that too. (Interview, 2010)

Unlike food from food banks, which are not present in rural communities in Northern Manitoba, country food is prestigious in receiving food that is nutritious and of high quality. The Nelson House Country Food Program fosters natural capital through stewardship. The program teaches conservation principles, such as not fishing 
when fish are spawning or hunting moose, caribou, or deer during calving season. NCN Conservation activities have resulted in the re-establishment of a caribou herd nearby. NCN has also developed a wildlife management plan in light of the many negative impacts of Manitoba Hydro's Churchill Diversion, which has decimated and contaminated fish, muskrat, wild geese, and other wildlife populations in the area. Country food workers are forced to travel outside their reserve to hunt and fish, traveling by train, for example, to Churchill where there is an abundance of geese.

As shown in Table 4, the country food program improves food security, sustainable livelihoods, and food sovereignty. Country food sharing, to a lesser degree, occurs in all Aboriginal communities but without community supports and so individuals bare the heavy cost of provisioning. However, NCN is inspiring others; both South Indian Lake FN and Garden Hill FN are devising their own country food programs that would work within existing regulations.

\section{Access to the market place in Northern Manitoba}

13 of the 14 communities studied have either no grocery store or have only one grocery store that stocks mainly high-calorie, high-fat, low-nutrient food, and supplies little in the way of fruits and vegetables. Only the fly-in community of Berens River FN has three grocery stores, in this case because there is a barge that ships food in all year long. The only grocery store in most communities is the Northern Store (only Leaf Rapids has a Federated Co-operative store, with local people serving as the manager and on its board). Northern Stores is a publicly traded company operated until 1987 by the Hudson Bay Company, and now under the ownership of The North West Company. The Northern Store has a policy of employing managers external to the community, which limits local decision-making, human capital development, and food sovereignty. A typical Northern Store controls every economic aspect of community's food supply with high profits flowing out of the community. The cost and quality of food is often inadequate to support healthy dietary choices, as one community member in Wasagamack commented, "[t]he existing Northern Store's selection is very limited and costly. After shipping, the produce is often damaged" (Interview, 2011a).

The logit model analysis for number of grocery stores in the community (OR 1.85, 95\% $\mathrm{Cl} 1.26-2.70, \mathrm{P}<0.01)$ suggests that food security benefits from increased competition of grocery stores, in terms of both pricing and quality. As shown in Figure 5, food security rates are predicted to increase from $25 \%$ when there is no grocery store present, to $69 \%$ when there is competition amongst three grocery stores in a community. This lack of stores in communities along the Bayline Railroad, including Thicket-Portage, llford, and War Lake FN, as well as the fly-in community of Granville Lake, shows how the marketplace has abandoned small Northern communities. 
Table 4: Impact of food-related economic development on sustainable
livelihoods, food security and food sovereignty

\begin{tabular}{|c|c|c|c|c|c|c|c|}
\hline Programs & $\begin{array}{l}\text { Financial } \\
\text { capital }\end{array}$ & Natural capital & $\begin{array}{l}\text { Physical } \\
\text { capital }\end{array}$ & $\begin{array}{l}\text { Human } \\
\text { capital }\end{array}$ & $\begin{array}{l}\text { Social } \\
\text { capital }\end{array}$ & $\begin{array}{l}\text { Food } \\
\text { sovereignty }\end{array}$ & Food security \\
\hline $\begin{array}{l}\text { Chronic } \\
\text { Disease } \\
\text { Prevent-ion } \\
\text { Initiative }\end{array}$ & $\begin{array}{l}+/-\$ 2 \text { per } \\
\text { capita is } \\
\text { very limited } \\
\text { budget for a } \\
\text { program. }\end{array}$ & $\begin{array}{l}\text { + Local garden } \\
\text { materials and } \\
\text { fishnets reduce } \\
\text { food miles. }\end{array}$ & $\begin{array}{l}+ \text { l- Walking } \\
\text { trails. } \\
\text { Fish Nets. }\end{array}$ & $\begin{array}{l}\text { + Nutrition, } \\
\text { health, } \\
\text { gardening, } \\
\text { preserving } \\
\& \text { wild food } \\
\text { harvesting }\end{array}$ & $\begin{array}{l}\text { + Feasts } \\
\text { share } \\
\text { country } \\
\text { foods with } \\
\text { community }\end{array}$ & $\begin{array}{l}\text { + Supports } \\
\text { local production } \\
\text { of gardens, wild } \\
\text { meat, berries \& } \\
\text { fishing. }\end{array}$ & $\begin{array}{l}\text { +Limited } \\
\text { impact on } \\
\text { food security. }\end{array}$ \\
\hline $\begin{array}{l}\text { Northern } \\
\text { Healthy } \\
\text { Food } \\
\text { Initiative }\end{array}$ & $\begin{array}{l}\text { Loans to } \\
\text { buy freezers } \\
\text { for social } \\
\text { assistance } \\
\text { recipients. }\end{array}$ & $\begin{array}{l}\text { + Local garden } \\
\text { materials and } \\
\text { chickens reduce } \\
\text { food miles. }\end{array}$ & $\begin{array}{l}+/- \text { No tractors } \\
\text { or commercial } \\
\text { facilities. } \\
\text { Plastic and } \\
\text { rototillers } \\
\text { provided. }\end{array}$ & $\begin{array}{l}\text { +Education } \\
\text { on food } \\
\text { preserving, } \\
\& \text { gardens. }\end{array}$ & $\begin{array}{l}+/- \\
\text { Interaction } \\
\text { with NGOs } \\
\text { but limited. }\end{array}$ & $\begin{array}{l}\text { - Little or no } \\
\text { community } \\
\text { choice of } \\
\text { programs } \\
\text { No funding for } \\
\text { wild foods } \\
\text { programming. }\end{array}$ & $\begin{array}{l}\text { + Limited } \\
\text { impact on } \\
\text { food security. }\end{array}$ \\
\hline $\begin{array}{l}\text { School } \\
\text { lunch and } \\
\text { welfare food } \\
\text { buying club } \\
\text { programs }\end{array}$ & $\begin{array}{l}+/ \text { - Extends } \\
\text { food } \\
\text { budgets. } \\
\text { Money flows } \\
\text { out of } \\
\text { community }\end{array}$ & $\begin{array}{l}\text { - Food miles } \\
\text { from flying in } \\
\text { foods. }\end{array}$ & $\begin{array}{l}\text { - Does not } \\
\text { build physical } \\
\text { capital. }\end{array}$ & $\begin{array}{l}+ \text { Cooks in } \\
\text { schools } \\
\text { make } \\
\text { healthy } \\
\text { meals. }\end{array}$ & $\begin{array}{l}+ \text { Meals at } \\
\text { school allow } \\
\text { youth to } \\
\text { learn better. }\end{array}$ & $\begin{array}{l}+/- \text { No local } \\
\text { purchases (e.g., } \\
\text { fish, wild meat, } \\
\text { etc.) Food } \\
\text { choices not } \\
\text { limited by } \\
\text { monopoly. }\end{array}$ & $\begin{array}{l}\text { + Cheap } \\
\text { meals has } \\
\text { positive } \\
\text { impact for } \\
\text { students on } \\
\text { food security. }\end{array}$ \\
\hline $\begin{array}{l}\text { Fish buying } \\
\text { club }\end{array}$ & $\begin{array}{l}\text { + Higher } \\
\text { returns for } \\
\text { fishermen } \\
\text { Gas \$ for } \\
\text { bycatch. }\end{array}$ & $\begin{array}{l}+ \text { Markets for } \\
\text { by-catch rather } \\
\text { than dumping } 3 / 4 \\
\text { of fish through } \\
\text { health centre. }\end{array}$ & $\begin{array}{l}\text { - Freezer in } \\
\text { health centre } \\
\text { \& some } \\
\text { market stalls. }\end{array}$ & $\begin{array}{l}\text { + Some } \\
\text { training on } \\
\text { marketing \& } \\
\text { business. }\end{array}$ & $\begin{array}{l}\text { + Neechi } \\
\text { Foods } \\
\text { partnership } \\
\text { - }\end{array}$ & $\begin{array}{l}\text { + Local control } \\
\text { over markets } \\
\text { and prices. } \\
\text { - Local } \\
\text { consumption } \\
\text { facilitated. }\end{array}$ & $\begin{array}{l}\text { +/-Uncertain. } \\
\text { Expect it will } \\
\text { be similar to } \\
\text { country foods } \\
\text { program. }\end{array}$ \\
\hline $\begin{array}{l}\text { Country } \\
\text { food } \\
\text { program }\end{array}$ & $\begin{array}{l}+ \text { Food \$ } \\
\text { stays on } \\
\text { reserve \& } \\
\text { employs } 7 \\
\text { workers at } \\
\text { NCN. } \\
\end{array}$ & $\begin{array}{l}+ \text { Hunting \& } \\
\text { fishing wildlife } \\
\text { conservation. } \\
\text { Re-established } \\
\text { a caribou herd. }\end{array}$ & $\begin{array}{l}+ \text { Food } \\
\text { processing } \\
\text { and storage } \\
\text { facility for wild } \\
\text { meat. }\end{array}$ & $\begin{array}{l}+ \text { Trains } \\
\text { youth in } \\
\text { traditional } \\
\text { country } \\
\text { foods. }\end{array}$ & $\begin{array}{l}\text { Country } \\
\text { foods } \\
\text { provided to } \\
\text { elders and } \\
\text { single } \\
\text { mothers. }\end{array}$ & $\begin{array}{l}+ \text { Locally } \\
\text { controlled } \\
\text { wildlife } \\
\text { management } \\
\text { and food } \\
\text { production. }\end{array}$ & $\begin{array}{l}\text { Statistically } \\
\text { significant } \\
\text { related to } \\
\text { better food } \\
\text { security. }\end{array}$ \\
\hline $\begin{array}{l}\text { Stores: } \\
\text { Northern } \\
\text { store }\end{array}$ & $\begin{array}{l}\text { - Food \$ } \\
\text { travels out } \\
\text { of } \\
\text { community } \\
\text { without } \\
\text { benefit to } \\
\text { locals. }\end{array}$ & $\begin{array}{l}\text { - No purchase } \\
\text { of local harvest. } \\
\text { Sell boats, } \\
\text { skidoos and } \\
\text { rifles at high } \\
\text { cost. }\end{array}$ & $\begin{array}{l}\text { - Store } \\
\text { buildings use } \\
\text { diesel, which } \\
\text { often leak \& } \\
\text { pollutes. }\end{array}$ & $\begin{array}{l}\text { +/- Limited } \\
\text { job \& } \\
\text { training } \\
\text { provided } \\
\text { with } \\
\text { outsider } \\
\text { managers. }\end{array}$ & $\begin{array}{l}\text { - High } \\
\text { mark-up of } \\
\text { fruits \& } \\
\text { vegetables } \\
\text { but cheap } \\
\text { processed } \\
\text { food fuels } \\
\text { diabetes. }\end{array}$ & $\begin{array}{l}\text { - No } \\
\text { community } \\
\text { control over } \\
\text { food types or } \\
\text { products or } \\
\text { profit margin. }\end{array}$ & $\begin{array}{l}\text { - Higher rates } \\
\text { of food } \\
\text { insecurity } \\
\text { (>75\%) vs. } \\
\text { co-op or } \\
\text { community } \\
\text { store. }\end{array}$ \\
\hline $\begin{array}{l}\text { Commercial } \\
\text { fishing in } \\
\text { North }\end{array}$ & $\begin{array}{l}\text { + Fish co- } \\
\text { ops not } \\
\text { viable as } \\
\text { fishers have } \\
\text { high costs \& } \\
\text { low returns. }\end{array}$ & $\begin{array}{l}-3 / 4 \text { of fish } \\
\text { caught are } \\
\text { dumped due to } \\
\text { quote or with } \\
\text { pickerel only } \\
\text { feasible. }\end{array}$ & $\begin{array}{l}\text { + Fish plant at } \\
\text { Leaf Rapids \& } \\
\text { Garden Hill } \\
\text { but badly } \\
\text { designed by } \\
\text { government. }\end{array}$ & $\begin{array}{l}+ \text { Limited to } \\
\text { family as } \\
\text { fishing } \\
\text { boats small } \\
\& \text { high cost. }\end{array}$ & $\begin{array}{l}+ \text { Food } \\
\text { removed } \\
\text { from } \\
\text { community } \\
\text { at very low } \\
\text { exchange } \\
\text { value. }\end{array}$ & $\begin{array}{l}\text { - Fishers lack } \\
\text { control over } \\
\text { markets. Unable } \\
\text { to sell to local } \\
\text { public facilities. }\end{array}$ & $\begin{array}{l}\text { - Fishers had } \\
100 \% \text { food } \\
\text { insecurity due } \\
\text { to high costs } \\
\text { \& low returns. }\end{array}$ \\
\hline
\end{tabular}

Legend: - negative impace; +/- limited or no impact; + postive impact 


\section{Figure 6: Probability of having household food security based on number of grocery stores when a community is not accessible by road and public transport but country food programs are available}

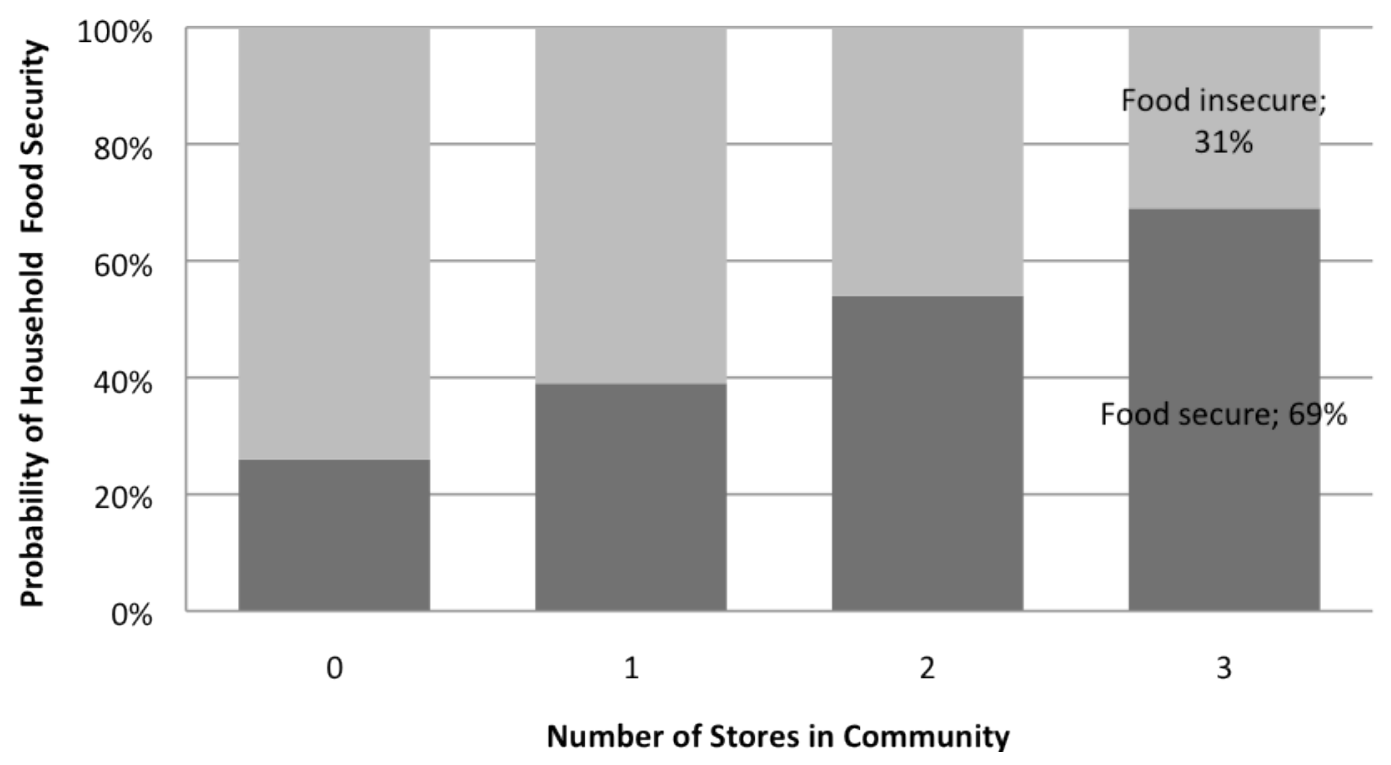

In Northern Manitoba, access to the cheaper and healthier retail food found in urban centres is an important contributor to food security. In the logit model, access to roads had the second largest impact on food security (OR $7.60,95 \% \mathrm{Cl} 1.12-51.50, \mathrm{P}<0.05$ ). Figure 1 shows that ten of the 14 communities surveyed do not have access to an all-weather road, including six that are only accessible by plane. In these communities food must be flown in all year round (except for four communities, when for a few weeks each year winter roads are open).

Public transit (e.g., train or bus) to access healthier food at cheaper prices is either not available or is very limited, and most people cannot afford private transportation. Public transit was positively related to food security (OR 3.90, 95\% Cl 1.52-9.90, P<0.01). When Grey Goose Bus-line shut down service to the ANA communities of Leaf Rapids and Lynn Lake in May of 2012 healthy food became less accessible, which negatively impacts food security. Although public transit is available along the Bayline Railroad, access to food is thwarted by the lack of a commuter train to stores in Thompson or Churchill. As a result, a trip to the grocery store takes several days, requiring at least $\$ 250$ in additional expenses for hotel, taxi, and train. Community members along the Bayline Railway discussed how the train conductor used to buy vegetables from market gardens in Thicket-Portage to sell at the other stations en route to Churchill and the need to bring this train market back.

To determine the relative cost of healthy food, in 2009 the price of food items listed in the NNFB was compared at the stores in the 14 surveyed communities, as well as at 22 stores in Southern Manitoba. This standardized grocery list cost $\$ 418$ in fly-in communities compared to $\$ 302$ in the five Northern Manitoba rural communities with roads, and \$233 in stores in Southern Manitoba. On average, when compared to Northern communities with roads, the entire NNFB food list in fly-in communities is found to be $38 \%$ higher, and specifically $79 \%$ higher for the fruits and vegetables category ( $\$ 134$ for fly-in communities compared to $\$ 75$ for Northern communities with roads). Higher prices in fly-in communities reflect freight costs for flying in food, but also the lack of competition in these communities that results in price gouging. Even though Nutrition North provides 
subsidies for freight brought into fly-in communities, prices in stores for healthy foods are much higher than unhealthy food. Community members convey their suspicions that the federal subsidy "Nutrition North Canada" (previously called the "Food Mail Program" run by the Northern Store in Manitoba, is not being passed onto the consumer. As one community health person aptly described: "When an educator of Nutrition North comes - the food will go down for a short time but soon it is back up to a much higher price" (Interview, 2011). Stores benefit from this government subsidy but the consumers do not.

Access to a store within a community is also an issue, as most communities either lack a store or the store is located outside the community. However, the logit model did not find access to a store within walking distance to have a significant relationship to food security. Northern Stores location is typically located off reserves, which presents a barrier to food access and removes the store's physical capital from the community. For example, the Northern Stores, at both Garden Hill FN and at Wasagamack FN, are located on a separate island adjacent to the community. To get groceries during ice formation and ice break-up, which lasts for about a month in both the fall and spring, people risk their life or must charter a helicopter (which is very expensive). When there is open water, people spend much of their limited food budget to rent a boat taxi.

Communities need alternatives to the monopoly of the Northern Store. In 2012, South Indian Lake FN decided to develop a business plan for a community or co-operative grocery store, and plans are also underway in Garden Hill FN. Food buying clubs are another potential solution.

\section{Food buying clubs and the Nutrition North Canada program in Northern Manitoba}

Food buying clubs are simply a group of people who come together and save money by purchasing food in bulk. In fly-in locations, food buying clubs access the Nutrition North freight subsidy. According to the logit model, however, despite Nutrition North and food buying clubs, the lack of roads continues to have a significant negative impact on food security.

Schools and FN social welfare departments organize the largest food buying clubs in Northern Manitoba communities. For example, in the four fly-in Island Lake FN communities, bulk food packages are ordered from Winnipeg stores by schools and social assistance workers, ensuring healthier foods, school lunches (human capital) and better prices for clients (economic capital). In St. Theresa Point FN, the social assistance worker reports ordering about $\$ 60,000 /$ month of mainly meat packs from Winnipeg. The costs are then deducted from the clients' next social assistance cheque. The principal of the secondary school at Garden Hill FN orders in bulk ( $\$ 1200 /$ month) from Winnipeg stores to provide a hot school lunch and snack program that the students each pay $\$ 15$ per month for. However, the school lunches are usually pasta-based, and attempts to use local meats and fish have resulted in the local school cafeterias being shut down by the Federal Public Health Inspector (Interviews, 2011) due to regulations preventing uninspected meat and fish being sold locally. The food miles required to fly food in to communities rather than using local country foods and supporting local harvesters, reduces natural, social, and physical capital development.

\section{Chronic disease prevention initiative}

The Chronic Disease Prevention Initiative (CDPI) is a permanent government program created to improve the health of Manitobans through local partnerships, citizen engagement, and community development. A community CDPI team decides how to spend the limited CDPI financial capital for programming ( $\$ 2$ per capita), with local Aboriginal Diabetes Initiative (ADI) staff providing support and education. This partnership provides some support for food sovereignty in decision-making. 
CDPI often supports household food provisioning by funding fishing nets and seeds, as well as engaging in education regarding gardening, nutrition, canning, and cooking. Gardening has a significant positive relationship to food security according to the logit model (OR $1.41,95 \% \mathrm{Cl} 1.01-1.81, \mathrm{P}<0.01)$, in contrast to household hunting and fishing. Figure 7 shows that as garden provisioning increases from none to all that is required to sustain a household food security is predicted to increase from $38 \%$ to $72 \%$. A few families were able to harvest and preserve sufficient vegetables so that they continued to be a regular part of their diet year-round, however this is highly unusual given the short growing season and poor soil conditions in these northern locations, and without the aid of tractors, commercial greenhouses, or other farming equipment.

Many households cannot actively hunt and fish due to the high price of gas, materials, and equipment (e.g., skidoos and boats), and the long distances they must travel to get to trap lines (sometimes located in neighbouring provinces, and requiring a float plane or helicopter to get to). The people who can afford to hunt and fish (i.e., who have sufficient income), prize the time they get to spend engaging with traditional activities and food, however do not see hunting as a cost-saving activity. Gas is much higher in some of these communities (for example in August 2012 in Garden Hill FN gas was $\$ 2.50 /$ litre). A positive relationship was found between household hunting and fishing and food security, showing the need for a country foods program to provide some community-level assistance for food storage facilities, gas, equipment, vehicles and/or training.

\section{Figure 7: Probability of having household food security based on how much you eat from your garden when the community is not accessible by road or public transport but country food programs are available}

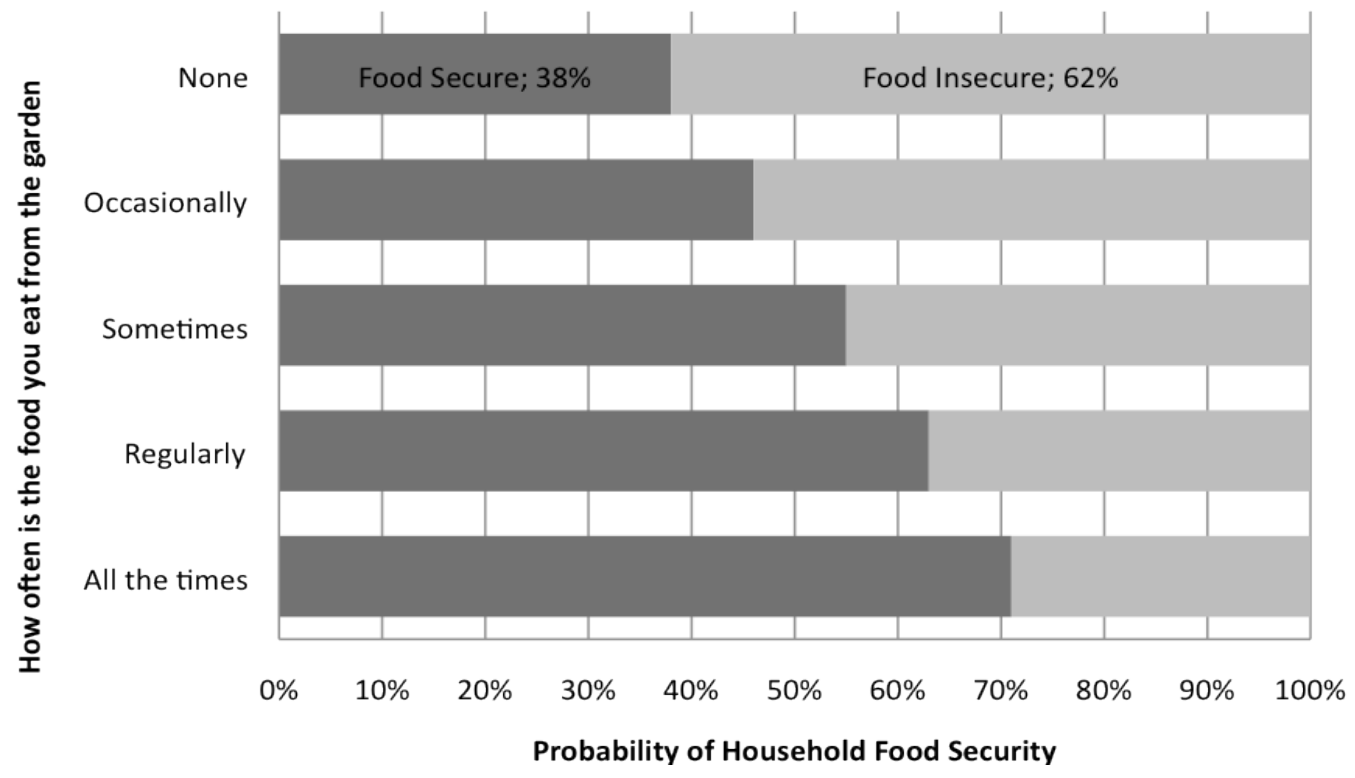

Country food and gardening activities are popular and support both the active living and nutrition objectives of CDPI. One ADI worker for the four Island Lake communities commented about how important it is to provide access to plants and seeds: "Definitely these folks for transportation reasons can't go to town to a plant or grocery store because of economics" (Interview, 2010). An ADI worker in Garden Hill discussed the human and social benefits of a special training program for: "youth [to] learn how to ... garden ... taught by the Elder. To have the youth and the Elders interact because we're always being told that our teachings come from the Elders" (Interview, 2011). Larry Wood, another ADI worker at Garden Hill FN, found that the nets funded by 
CDPI had extensive positive impacts on each fisher's extended family: "An ice fishing net can each feed 20 families or about 150 to 200 people" (Interview, 2010). Also, communities often decide to fund country food feasts for the community, building social capital and providing an income to local people who go out on the land and then prepare and cook the food. Thus, CDPI has small benefits to natural, social, financial, and human capitals, food security and food sovereignty.

\section{The Northern Healthy Food Initiative}

The Northern Healthy Food Initiative (NHFI) led by ANA was designed to increase food self-sufficiency in Northern Manitoba. The NHFI provides gardening materials, greenhouse plastic, chicken or turkey starter kits, and loans for freezers. With few of these items present in most Northern communities prior to NHFI, their presence has resulted in noticeable changes and enthusiasm at the community level. By 2009, the freezer loan program financed 271 freezers in 22 communities (with about 100 in the 14 communities surveyed) through a revolving loan (Thompson et al., 2010a). NHFI (and CDPI) inputs have increased the number of gardens that are being cultivated (from 148 in 2008 to 180 in 2009) and the number of greenhouse installations (from six to 16 over the same period) (Thompson et al., 2010a). Although greenhouses extend the growing season they were not found to be statistically significant to food security in the logit model.

The five NGOs appointed by the provincial government to determine communities' priorities regarding materials and workshops, operate without a lot of community input and undermine local food sovereignty efforts. Some Northerners feel one NGO in particular, was "useless," with a person from Leaf Rapids labeling them, "paper shufflers in Winnipeg who come to the north for photo opportunities rather than to help, and leave the same day" (Interview, 2010). The designer of NHFI, Jacinta Wiebe (2012), discussed the program's bureaucracy and funding shortfalls:

I designed the prototype projects to address the particular needs of the isolated and remote communities as they have higher transportation food costs and higher rates of diabetes. ... After submitting modest budgets to provide start up funding for these communities, we were told that funding was not available. ... To this day, minimal funding is provided to cover mainly administrative salaries in government, political and health organizations housed in urban areas to carry on this important initiative for Aboriginal peoples living in the communities (Wiebe, 2012).

The impact on sustainable livelihoods of NHFI is limited. Human capital is undermined when NGOs hire "Winnipegers" rather than community members, and by funding, characterized here by one NGO worker: "Unstable funding, a lack of continuity, etc. has led to a great deal of turnover of good staff at the regional project level" (Interview, 2010). Limited NHFI funding provides only enough funding for small-scale household gardens, which provides food and natural capital and builds social and human capital, through sharing and education, but not market garden.

\section{Commercial fishing}

Commercial fishing has been a key economic activity for Aboriginal people since the industry developed in the 1880s, and has been increasingly important to FNs' income since the decline of the fur trade (Tough, 1984). In 2006-2007, Northern Manitoba commercial fishers generated \$16-million in revenues, accounting for $66 \%$ of the provincial catch by weight (Northern Development Ministers Forum, 2010). The settlers' commercial fishing industry overtook FN subsistence fisheries with larger boats and better technology (Tough, 1984). To this day,

\section{ANSERJ To be notified about new ANSERJ articles. click subscribe.}


many FN commercial fishers in Northern Manitoba lack advanced technology, with most only having a small two-person speedboat and gill fishing nets to work with.

Every aspect of fishing is controlled by government, which undermines food sovereignty. Manitoba Conservation manages fish resources with quotas and restrictions on the mesh size of gill nets, and by placing limitations on the duration of fishing seasons and the annual number of fishing licenses. As an example, Manitoba Conservation confiscated the ice fishing net that Elders had set for the filming of Harvesting Hope the very same day it was set, disempowering the people involved. Not only is the how, what, and when of fishing regulated by Non-Aboriginals, but also the where and what of sales. In 1969 the Freshwater Fish Marketing Corporation (FFMC) was established (Freshwater Fish Marketing Corporation, 2010) to regulate all sales of fish, and today most fishers can only sell to them. Garden Hill Fishery is one of a few fisheries that obtained an export license from FFMC, but this license is also restricted, as it only allows them to sell pickerel to one business in Ontario. This regulation negates food sovereignty and undermines food security. All nine fishermen surveyed from Garden Hill were severely food insecure (Islam \& Thompson, 2011).

In focus groups, fishers reported that their sales were limited to pickerel, representing only $25 \%$ of their total catch each day (Thompson et al., 2011), with the remaining $75 \%$ being by-catch (e.g., white fish, lake trout, walleye, suckers, perch, etc.) that is currently thrown away. According to local fisherman Chris Taylor, "it is very hard to survive with fishing by selling only one species. We throw away all the other fish by the river bank as we can't afford the gas to haul all of them" (Interview, 2011). As a result, fishers in Northern Manitoba cannot make a decent living and their livelihoods are unsustainable. The low price they get for fish is eroded by the high cost of the means of production (purchase price and interests rate for boats, nets and snowmobiles) and very high transportation costs. Whole fish, which are 50 to $60 \%$ heavier than filleted fish, (Thompson et al., 2011a) must be flown out because the community is only licensed to pack fish and not to process them.

\section{Fish buying club}

Garden Hill Fishery is currently organizing a Fish Buying Club that would allow fishers to sell the abundant and high-quality fish available in pristine Island Lake, directly to consumers. This would enable them to get higher prices and organize co-operatively. In 2012, Garden Hill FN endorsed the Fish Buying Club with a Band Council Resolution. During a focus group discussion in 2011 the fishermen stated their desire to create a market for the by-catch species, thereby diversifying and increasing their income. The fishers also wanted to process and sell value-added fish products locally and abroad (including fish filets and smoked fish), rather than only selling whole fish. Greater local provisioning would increase food security, social capital, and food sovereignty.

The Fish Buying Club is building additional capital for the community. Neechi Foods Co-operative-a fish vendor for over 20 years that focuses on Aboriginal community economic development-and $U$ of $M$, have joined forces with the Garden Hill Fishery to increase human and social capitals. Neechi Foods and U of M have helped Garden Hill Fishery to obtain a special dealer's license, which permits the fishery to sell directly, to among other places, farmers markets, restaurants, schools, and stores in Garden Hill at higher prices, thereby increasing financial capital. A video-based commercial and marketing platform was also created by $U$ of $M$ to help fishers market their fish (available at http://fromgardenhill.blogspot.ca/). As well, the Garden Hill Community Health Centre is working with $\mathrm{U}$ of $\mathrm{M}$ to start a small-scale country foods program that uses fish by-catch as part of their ADI program. 


\section{CONCLUSION}

Exploring food-related activities and their impacts on sustainable livelihood assets, food sovereignty, and food security provides a holistic picture of outcomes and impacts. Food security analysis shows the need for foodrelated activities and the impact of different activities on reducing hunger. Food sovereignty meanwhile analyzes the level of community control. Finally, the sustainable livelihood analysis is important to show whether foodrelated activities build community capacity.

The high rate $(75 \%)$ of food insecurity in Northern Manitoba communities is unacceptable, as is the lack of safe drinking water, road access, healthy housing, and other necessary infrastructure for healthy living. Development to improve food security can be improved immediately through local solutions, such as funding a country foods program. To improve food security at the regional level in the long-term, government investment is needed to improve infrastructure in Northern communities (e.g., roads, safe water systems, housing, and public transit). Food-related interventions are badly needed but their impact on food security, food sovereignty, and sustainable livelihoods should be considered from an Indigenous worldview.

Country food programs are an important option for communities to consider as they can increase all of the sustainable livelihood assets, and help build food sovereignty. According to the logit model, sharing country foods improves food security more than any other variable. The model predicts an increase in the rate of food security in the surveyed communities from $25 \%$ to $40 \%$, and when combined with access to public transit and roads, this increases to $95 \%$. However, even low-cost activities, such as sourcing all vegetables from local gardens, is predicted to raise the food security rate to $70 \%$, when combined with the country food program; neither gardens nor country food programs require massive infrastructure. The Nelson House Country Foods Program negotiated the barriers imposed by the Manitoba Public Health Act and The Food and Food Handling Establishment Regulations regarding the selling or serving of local fish or meat without inspection in a federal food facility, by establishing a tracking system. Inspired by this program, South Indian Lake FN and Garden Hill FN have formed local committees to develop country food programs and are trying to take control over their food retail by developing stores in their communities. Communities would benefit from health authorities establishing local committees to allocate funding for local solutions (similar to what happened in BC), so as to maximize food sovereignty and community assets.

The market system in Manitoba that includes the Northern Store and commercial fishing provides neither food security nor sustainable livelihoods, and works against food sovereignty. Remote communities without roads suffer from high freight rates to both fly food in and fly fish out, and yet government restrictions prohibit the public sale and consumption of wild fish and meat locally. The dominant market force in Northern Manitoba is profit, rather than a community-driven chain of Northern Stores. In contrast, the Arctic Co-op in Nunavut is governed locally to meet community needs and build assets. Community stores build community assets and food security, as does more competition between stores to prevent price gouging. However, funding to subsidize freight for retail foods through Northern Stores is money badly spent, and undermines food sovereignty and sustainable livelihoods. If food is to be subsidized the program should support the poor rather than corporate entities.

Fishing is one of the few livelihoods in Northern Manitoba but the regulations and marketing restrictions make it unsustainable, with fishers suffering from high food insecurity. Fishers have high costs for outfitting and transporting fish south, but without any other market options, they receive low prices for pickerel, and due to regulation and markets, nothing for by-catch. Fishers should be able to process and sell pickerel and by-catch locally and elsewhere to gain higher prices and maintain their livelihoods.

\section{ANSERJ To be notified about new ANSERJ articles. click subscribe.}


Gardening provides some positive outcomes in communities. NHFI and CDPI programs stimulate home and community gardens and greenhouses, and provide freezer loans and a few poultry starter kits. The impacts of these programs vary based on productivity in the small number of participating homes. Agricultural programs should to be scaled up to facilitate market gardens that can sell locally and in other communities. For NHFI and all other food activities, community control over funding and decision-making without undue restrictions on country foods is key to food access in Northern Manitoba.

\section{ACKNOWLEDGEMENTS}

Thank you to all the community members, particularly Larry Wood, Byron Beardy, and Chuck Stensgard for your valuable input. Our gratitude also goes to the reviewers for their insightful comments and the excellent copy editors, Perry Stein and Marilyn Bittman, and editor, Peter Elson.

\section{INTERVIEWS}

Interview. 2010. Aboriginal Diabetes Initiative (ADI) Worker, Island Lake FN communities. Interviews. 2011. Cafeteria worker and teacher in St. Theresa Point FN. Interview. 2010. Community member in Leaf Rapids, MB. Interview. 2010. Charlie Hart, Manager, Nelson House Country Food Program, NCN FN. Interview. 2010. Non-government Organization worker paid by Northern Healthy Food Initatives. Interview. 2010. Ron Spence, NCN FN, Councilor, NCN FN, MB, and previous Conservation Manitoba Wildlife Officer. Interview. 2011. Chris Taylor, Garden HIII FN, President, Garden Hill Fisheries Association. Interview. 2010. Larry Wood, Garden Hill FN, Aboriginal Diabetes Initative Worker. Interivew. 2012. Jacinta Wiebe, NHFI designer, The Pas, Manitoba.

\section{REFERENCES / BIBLIOGRAPHIE}

Altieri, M.A. (2008). Small farms as a planetary ecological asset: Five key reasons why we should support the revitalization of small farms in the global South: Insitute for Food and Development Policy. URL: http://www.foodfirst.org/en/ node/2115 [December 10, 2011].Arctic Co-op Limited. (2012).

Arctic Co-operative webpage. URL: http://www.arcticco-op.com/index.htm. [August 5, 2012].

Ballard, Myrle. 2012. Flooding sustainable livelihoods of the Lake St Martin First Nation: The need to enhance the role of gender and language in Anishinaabe knowledge systems. Ph.D. Thesis Dissertation. Natural Resources Institute, University of Manitoba, Winnipeg, Manitoba.

Bickel, G., Nord, M., Price, C., Hamilton, W., \& Cook, J. (2000). Measuring food security in the United States: Guide to measuring household food security. Alexandria, VA: United States Department of Agriculture; Office of Analysis, Nutrition, and Evaluation.

BC Health. (2012). Food Security and Community Food Plans. URL: http://www.health.gov.bc.ca/healthyeating/foodsecurity.html [June 12, 2012].

Brocklesbury, M., \& Fisher, A. (2003). Community development in sustainable livelihoods approaches - an introduction. Community Development Journal, 38(3), 185-198.

Carney, D. (1998). Sustainable Rural Livelihoods: What contribution can we make? London, UK: Department for International Development.

Chambers, R., \& Conway, G. (1992). Sustainable rural livelihoods: Practical concepts for the 21st century (No. 296 IDS Discussion Paper). Brighton, UK: Institute of Development Studies, The University of Sussex.

Che, J., \& Chen, J. (2001). Food insecurity in Canadian households. Health Reports, 12, 11-22. 
Churchill, W. (1999). Struggle for the land: Native North American resistance to genocide, ecocide and colonization. Winnipeg, MB: Arbiter Ring Publishers.

Cohen, B. (2002). Community Food Assessment Toolkit. EFAN. USDA. URL: http://www.ers.usda.gov/Publications/ EFAN0213 [Retired, October 21, 2011].

Department of Foreign Affairs and International Development (2001). Sustainable livelihoods guidance sheets. London, UK: Department for International Development.

Department of Foreign Affairs and International Development (2008). Annual report. Development: Making it happen. URL: http://www.dfid.gov.uk/Documents/publications1/departmental-report/2008/Cover-prelims.pdf [October 16, 2011].

Douglas, D.J.A. (1994). Community economic development in Canada. Toronto, ON: McGraw-Hill Ryerson.

Eidse, D. \& Thompson, S. [Producer]. (2011). The Burntwood Journey: Chronic Disease Prevention Initiative in Northern Manitoba. Video Commissioned by Burntwood Regional Health Authority, Thompson, Manitoba. [Video, 37 mins.]. URL: http://home.cc.umanitoba.ca/ thompso4 .

Ellis, F. (2000). Rural livelihoods and diversity in developing countries. Oxford, UK: Oxford University Press.

Feenstra, G. (1997). Local food systems and sustainable communities. American Journal of Alternative Agriculture, 12(1), $28-36$.

Freshwater Fish Marketing Corporation (2010). Freshwater Fish. URL: http://www.freshwaterfish.com/content/pages/supplychain-0 [October 22, 2011].

International Planning Committee for Food Sovereignty (2007). Declaration of Nyelini. URL: http://www.foodsovereignty .org/Portals/0/documenti\%20sito/Resources/Archive/Forum/2007/2007-En-Declaration_of_Nyeleni.pdf [July 1, 2012].

FAO (1996). World Food Summit: Rome declaration on world food security and world food summit plan of action. FAO: Special Advisers to the Director-General. URL: http://www.fao.org/docrep/003/w3613e/w3613e00.htm [October 16, 2011].

Ford, E.S., \& Mokdad, A.H. (2008). Epidemiology of Obesity in the Western Hemisphere. The Journal of Clinical Endocrinology \& Metabolism, 93(11), 1-8.

Friesen, M., \& Hudson, I. (2005). An analysis of Winnipeg's information and computer technology industry within a community economic development framework. Report prepared for Manitoba Research Alliance on Community Economic Development in the New Economy. URL: http://www.manitobaresearchalliance-tiac.ca/researchreports.html [October 22, 2011].

Greene, W. (1997). Econometric analysis. Upper Saddle River, NJ: Prentice Hall.

Health Canada (2007). Income-Related Household Food Security in Canada, Canadian Community Health Survey Cycle 2.2, Nutrition. Ottawa, Health Canada. HC Pub. No. 4696. Ottawa, ON. URL: http://www.hc-sc.gc.ca/fn-an/alt_formats/hpfbdgpsa/pdf/surveill/income_food_sec-sec_alim-eng.pdf [October 1, 2009].

Health Canada (2008). Methodology used to develop the 2008 National Nutritious Food Basket. Health Canada. URL: http://www.hc-sc.gc.ca/fn-an/surveill/basket-panier/method-eng.php [October 21, 2011].

Holt-Giménez, E., Patel, R., \& Shattuck, A. (2009). Food rebellions! Crisis and the hunger for justice. Boston, MA: Fahumu Books and Grassroots International.

Islam, D. (2011). Lake to plate, draft candidacy document. Winnipeg: Natural Resources Institute.

Islam, D. \& S. Thompson. (2011). Fishers food security and sustainable livelihoods. Poster presented at ESAC conference, Winnipeg, MB.

Khan, M. H. Z., \& Khan, M. R. (2010). Human capital disclosure practices of top Bangladeshi companies. Journal of Human Resource Costing \& Accounting, 14(4), 329-349.

Kirkpatrick, S., \& Tarasuk, V. (2008). Food insecurity in Canada: Considerations for monitoring. Canadian Journal of Public Health, 99(4), 324-327.

Kuhnlein, H. (2008). Indigenous peoples' food systems: Foundations of health in cultures and ecosystems. Paper presented at the Global Indigenous Health Research Symposium, University of Victoria, Victoria, B.C.

LaDuke, W. (2002). The Winona LaDuke Reader: A collection of essential writings. Penticton Indian Reserve, BC: Theytus Books.

Ledrou, I., \& Gervais, J. (2005). Food insecurity. Health Reports, 16, 47-50.

Li, A., Dachner, N., \& Tarasuk, V. (2009). Food intake patterns of homeless youth in Toronto. Canadian Journal of Public Health, 100(1), 36-40.

Long, S.J. \& Freese, J. (2001). Regression models for Categorical dependent Variables using STATA. College Station, Texas: Stata Press.

Markey, S., Pierce, J. T., Vodden, K., \& Roseland, M. (2005). Second growth: Community economic development in rural and small town. Vancouver, BC: UBC Press. 
Northern Development Ministers Forum (2010). Northern development ministers forum. Manitoba. URL: http://www .focusnorth.ca/english/province/manitoba.php [June 1, 2011].

Northern Food Prices Project Steering Committee [NFPSC] (2003). Northern food prices report 2003. Manitoba healthy child committee of cabinet. URL: http://www.gov.mb.ca/ana/food_prices/2003_northern_food_prices_report [March 1, 2011].

Patel, R. (2009). What would food sovereignty look like? The Journal of Peasant Studies, 36(3), 663-706.

Pindyck, R, \& Rubinfeld, D (1991). Econometric Models and Economic Forecasts, (Third Edition). New York, NY: McGraw-Hill.

Power, E.M. (1999). Combining social justice and sustainability for food security. In M. Koc, R. MacRae, L.J.A. Mougeot \& J. Welsh (Eds.), For hunger proof cities: Sustainable urban food systems (pp. 30-37). Ottawa, ON: International Development Research Centre.

Power, E.M. (2008). Conceptualizing food security for Aboriginal people in Canada. Canadian Journal of Public Health, 99(2), 95-97.

Power, E.M., \& Tarasuk, V. (2006). The impact of income on healthy eating in Canada. Health Canada Policy Forum \#60, March 23, 2006.

Riches, G. (1999). Advancing the human right to food in Canada: Social policy \& the politics of hunger, welfare and food security. Agriculture \& Human Values, 16(2), 203-211.

Scheier, L.M. (2005). Beyond the headlines. What is the hunger-obesity paradox? Journal of the American Dietetic Association, 105(6), 883.

Scoones, I. (1998). Sustainable rural livelihoods: A framework for analysis (No. 72 IDS Working Paper). Brighton, UK: Institute of Development Studies, The University of Sussex.

Selfa, T., \& Qazi, J. (2005). Place, taste or face-to-face? Understanding Producer-Consumer Networks in "Local" Food Systems in Washington State. Agriculture and Human Values, 22, 451-464.

Sen, A. (1983). Poverty and famines: An essay on entitlement and deprivation. Oxford: Oxford University Press.

Sheldrick, B. (2007). Community Economic Development: Governance and State-Civil society Relations Local Participation and Democratic State Restructuring. In J. Loxley et al. (Eds.) Transforming or Reforming Capitalism: Towards a Theory of Community Economic Development, (pp. 87-109). Winnipeg, MB: Fernwood.

Shragge, E. (2003). Activism and social change: Lessons for community and local organizing. Toronto, ON: University of Toronto Press.

Sonnino, R., \& Marsden, T. (2006). Beyond the divide: Rethinking relationships between alternative and conventional food networks in Europe. Journal of Economic Geography, 6(2), 181-199.

StataCorp. (2011) STATA: Data analysis and statistical software. College Station, Texas, USA.

Statistics Canada. (2006). 2006 Aboriginal population profile. URL: http://www12.statcan.ca/census-recensement/2006/dp$\mathrm{pd} / \mathrm{prof} / 92-594$ [September 12, 2011].

Szathmary, E.J.E., Ritenbaugh, C., \& Goodby, C.S.M. (1987). Dietary change and plasma glucose levels in an Amerindian population undergoing cultural transition. Social Science and Medicine, 24(10), 791-804.

Tarasuk, V. (Ed.). (2009). Health implications of food insecurity. In D. Raphael (Ed.), Social Determinants of Health: Canadian Perspectives [2nd Edition], (Chapter 14). Toronto, ON: Canadian Scholars' Press Inc.

Thompson, S. (2005). Sustainability and vulnerability: Aboriginal Arctic food security in a toxic world. In F. Berkes et al. (Eds.), Breaking ice: Renewable resource and ocean management in the Canadian North, (pp. 47-69). University of Calgary Press: Calgary.

Thompson, S. (Director/Videographer/Editor), Lozeznik, V., Klatt, R. (Ed.) (2009). Growing hope in Northern Manitoba communities [Video]. URL: http://home.cc.umanitoba.ca/ thompso4/Movie.html .

Thompson, S., Gulrukh, A., Fulford, S., Wong, K., \& Zahuriuk, S. (2010a). Report to Aboriginal and Northern Affairs Canada (INAC). Is healthy food on the table? An Evaluation of the Northern Healthy Food Initiative by people on the ground. Winnipeg, MB: Natural Resources Institute.

Thompson, S., Mailman, M., \& Gulrukh, A. (2010b). Is healthy food on the table in northern Manitoba? Evaluating northern healthy foods initiative for sustainability and food access. Winnipeg, MB: Natural Resources Institute.

Thompson, S., Mailman, M., Lozeznik, V., Gulrukh, A., Ballard, M. \& Islam, D. (2011a). Is community economic development putting healthy food on the table? Food Sovereignty in Northern Manitoba's Aboriginal communities. Journal for Aboriginal Economic Development, 7(2), 14-39.

Thompson, S. (co-Director/co-Producer), Lozeznik, V., Klatt, R. (Editor). (2011b). Harvesting Hope in Northern Manitoba Communities [Video, 37 mins.]. URL: http://home.cc.umanitoba.ca/ thompso4/harvestinghope_doc.html . 
Thouez, J.P., Rannou, A., \& Foggin, P. (1989). The other face of development: Native population, health status and indicators of malnutrition-the case of the Cree and Inuit of northern Quebec. Social Science and Medicine, 29(8), 965-974.

Torrez, F. (2011). La Via Campesina: Peasant-led agrarian reform and food sovereignty. Journal of Development, 54(1), 49-54.

Tough, F. (1984). The establishment of a commercial fishing industry and the demise of native fisheries in northern Manitoba. The Canadian Journal of Native studies, 4(2), 303-319.

United Nations Platform for Action Committee Manitoba (2006). Women and the economy. Economic alternatives: Community economic development. URL: www.unpac.ca/economy/ced.html. [October 16, 2011].

Usher, P., Duhaime, G., \& Searles, E. (2003). The household as an economic unit in Arctic Aboriginal communities, and its measurement by means of a comprehensive survey. Social Indicators Research, 61(2), 175-202.

Wiebe, J. (2012). Writing notes of Elder from Berens River and Northern Healthy Food Initiative Designer. The Pas, MB.

Willows N.D., Veugelers P., Raine K., \& Kuhle S. (2011) Associations between household food insecurity and health outcomes in the Aboriginal population (excluding reserves). Health Reports, 22(2), 15-20.

Willows N.D., Hanley A., \& Delormier T. (2012). A socioecological framework to understand weight-related issues in Aboriginal children in Canada. Applied Physiology, Nutrition, and Metabolism, 37(1), 1-13.

Wittman, H. (2009). Interview: Paul Nicholson, International Coordinating Council of La Via Campesina. The Journal of Peasant Studies, 36(3), 676-682.

\section{ABOUT THE AUTHORS / LES AUTEURS}

Shirley Thompson is Associate Professor, Natural Resources Institute, University of Manitoba Email:

s_thompson@umanitoba.ca

Asfia Gulrukh Kamal, is a PhD candidate in the Natural Resources Institute, University of Manitoba, Email: asfia.gulrukh@gmail.com

Mohammad Ashraful Alam is a PhD student in the Environment \& Geography Department, University of Manitoba. Email: alamma@gmail.com

Jacinta Wiebe, is an instructor in the Extension Division, Assiniboine Community College and Elder, Berens River First Nation. Email: jacinta.wiebe@gmail.com 